\title{
Egy túlterhelt fogalom
}

$\mathbf{N}$

$\mathbf{F}$

0

$\mathbf{R}$

$\mathbf{M}$

Á

C

I

Ó

S

$\mathbf{T}$

Á

$\mathbf{R}$

S

A

D

A

0

M

A tanulmány az információs társadalom mibenlétét sajátos módon határozza meg: eredettörténetének és intézményesülésének vázolásával bemutatja azt az utat, amely a társadalmi formáció aszimmetrikussá és túlterheltté válásához vezetett. A szerző szemantikai-pragmatikus közelítésmódot használ. Végkövetkeztetésként megállapítja: a) tudományos szempontból veszélyes a fogalmat uniformizálni vagy politikai ideológiává emelni, mert ezáltal b) elveszíti jelentésbeli és értelmezési lehetőségeinek sokszínűségét.

Kulcsszavak: információs társadalom, politikai ideológia, túlterhelt fogalmak, társadalmi formációk

\section{Szerzői információ:}

Balogh Gábor

Szociológus, a Pázmány Péter Katolikus Egyetem BTK Szociológiai Intézetének docense, a gazdaság- és menedzsmentszociológia specializáció, valamint a társadalmi tanulmányok BA-szak felelôse. A Budapesti Hittudományi Akadémián 1979-ben civilként teológiai egyetemi diplomát, az MKKE Közgazdasági Továbbképzố Intézetében 1987-ben szakközgazdász-oklevelet, majd a BKE-n 2003-ban szociológiából PhD-fokozatot szerzett. Fóbb kutatási területei: gazdaság- és menedzsmentszociológia, társadalombiztosítás-tan, információs társadalom, szociomatika.

E-mail: bgabor@btk.ppke.hu.

Így hivatkozzon erre a cikkre:

Balogh Gábor. „Egy túlterhelt fogalom”.

Információs Társadalom VI, 1. szám (2006): 22-29.

https://dx.doi.org/10.22503/inftars.VI.2006.1.3

A folyóiratban közölt müvek

a Creative Commons Nevezd meg! - Ne add el! - Így add tovább! 4.0

Nemzetközi Licenc feltételeinek megfelelöen használhatók. 


\section{Balogh Gábor \\ Egy túlterhelt fogalom}

Az „információs társadalom” szakkifejezéssel jelölt fogalom azok közé a fogalmak közé tartozik, amelyek sikere viszonylag rövid idő alatt és komoly „hátszélben” következett be. A történelemben ritkán fordul elő, hogy egy felülról vezérelt és pénzügyi eszközökkel támogatott fogalom intézménnyé válva világszerte ennyire egyértelmú fogadtatásra találjon a szakembereknél és a lakosság jelentős részénél. Hasonlóképpen ritkán tapasztalható, hogy egy fogalom égisze alatt olyan változások induljanak el, amelyek alapjaiban befolyásolják mindennapi és tudományos életünket.

E tanulmányban - a Nemzeti Hírközlési és Informatikai Tanács kezdeményezésére az információs társadalom mibenlétéról folyó vitához kapcsolódva-először magára a fogalomra és annak eredettörténetére koncentrálok, miközben egyes szemantikaipragmatikus vonatkozásokat is figyelembe véve vizsgálom a kifejezés tartalmát. A tanulmányt kitekintéssel zárom.

\section{A fogalom értelmezése és eredettörténete}

Maga az információs társadalom (IT) mint fogalom - anélkül, hogy etimológiai szófejtésbe bonyolódnék - két különbözố szakterületról származik: az információ mérnöki-technológiai, a társadalom pedig szociológiai értékorientációjú szemléletet feltételez. Az információs társadalom e kettő konvergenciájából létrejött sajátos alakzat. A konvergencia eredményeként a kifejezés új identitást vesz fel, és önálló entitásként funkcionál. Ettól kezdve az információs társadalom nem tekinthetố kizárólagosan sem mérnöki, sem technológiai, sem szociológiai formációnak.

A szakmai és a közéletben mintha aszimmetrikus fogalomként vált volna ismertté, és így terjedt el. Ezt a vélekedésemet alátámasztja, hogy a tudomány és politika irányadó körei eleinte a posztindusztriális társadalom ${ }^{1}$ szinonimájaként vagy informatikai és információtechnológiai jegyeit hangsúlyozva közelítették meg, és ilyen értelemben használták. Vannak társadalomtudósok, akik csupán új technológiai-politikai, illetóleg gazdasági paradigmát látnak benne, és vannak, akik ennél többet vélnek kiolvasni a szakkifejezésból. Az elóbbiekhez sorolandók - többek között - Daniel Bell (1974), a 60-as évek japán információs társadalmának meghatározó kutatói, a Research Institute of Telecommunication and Economics (RITE) és az Assosiation for Economic Planning (AEP)

${ }^{1}$ A posztindusztriális társadalomról az 1960-as évek végétól kezdôdô harmadik ipari forradalomnak köszönhetően beszélhetünk. A harmadik ipari forradalom idején az ipari társadalom gazdasági (szektorális) intézményei a technikai-technológiai fejlődés következtében jelentősen átalakulnak; technogazdasági átalakulás megy végbe. Az átalakulás hajtóerejét az információs és kommunikációs technológiák képezik. 
munkatársai, Franciaországból Simon Nora és Alain Minc (1979/1978/), az USA-ban az osztrák származású Fritz Machlup (1962, 1980-1984), illetóleg az ố nyomdokain haladó, de az OECD részére is dolgozó Marc Uri Porat (1977); vagy korábbi munkássága alapján a hálózatitársadalom-felfogás képviselóje, Manuel Castells is. Az utóbbiak (a többet kiolvasni vélók) közé tartoznak azok, akik holisztikusan közelítik meg és globális (általános) alakzatnak tartják, például az 1990-es években a „hurráoptimizmus” jegyében fogant megnyilatkozások, az EU-bürokraták jelentôs része, a Bangemann-jelentés összeállítói és az IT-elkötelezettek.

\section{Technológiai-politikai megközelítés}

Az említett személyek közül Daniel Bell inkább posztindusztriális társadalomnak, mint információs társadalomnak tekinti a társadalmi változások nyomán kialakuló új formációt. Felfogása szerint az új társadalmi berendezkedés a telekommunikáción (távközlésen) alapul, és „döntő hatással lehet a gazdasági és társadalmi tranzakciók lebonyolítására, a tudás előállítására és felhasználására, illetve az emberek foglalkozásának, munkájának jellegére. Az információ és a tudás szervezésének és feldolgozásának terén végbemenő forradalom, amelyben központi szerepet játszanak a számítógépek, az általam posztindusztriálisnak nevezett társadalom fejloodésének kontextusában zajlik le." ${ }^{2}$

A japán Tadao Umesao felfogása, akitól az „információs társadalom” kifejezés származik, szintén technológiai-gazdasági szemléletet tükröz. Umesao a gazdasági jelenségeket vizsgálva endodermális (mezőgazdaság, halászat), mezodermális (szállítás, nehézipar) és ektodermális (információ, kommunikáció, képzés) ágazatokat különböztet meg. Nyomdokain haladva a RITE és az AEP információkutató csoportjának (Information Study Group) munkatársai 1968-ban kísérletet tesznek az információs társadalom kritériumainak meghatározására. Fáradozásaik eredményeként 1971-ben a világon először elkészül az Az információs társadalom megteremtésének terve 2000-ig címú program, s politikai támogatással megkezdődik a Tama New Town építése, vagyis az információs társadalomnak mint technológiai-gazdasági paradigmának a megvalósítása a gyakorlatban. ${ }^{3}$

A kontinentális Európában a kezdet 1978-ra, a francia köztársasági elnök részére Simon Nora és Alain Minc által A számítógépesitett társadalom ${ }^{4}$ címmel készített jelentés kidolgozásának idejére tehető. További komoly előrelépés a Bangemann-jelentéshez (Europe and the Global Information Society) kapcsolódóan történik: felállítják az Information Society Project Office-t, és nekilátnak a program megvalósításának. Ezzel Japánt követően Európában is politikai síkra emelkedik a kifejezés tartalma. Értelmezése globális jelleget ölt, jelentése viszont nem lép túl a technológiai-politikai paradigma síkján. Maga a Bangemann-jelentés - ideértve az 1994. évi Fehér könyvet is - az információs társadalmat globális (holisztikus) jelenségnek tekinti, tartalmilag viszont az információs és kommunikációs technikákon alapuló társadalomként fogja fel és tárgyalja.

\footnotetext{
${ }^{2}$ Daniel Bell, 2001: 3.

${ }^{3}$ 2000-tól 2005-ig lezajlott az e-Japan (electronic Japan) program, 2006-tól pedig az úgynevezett $u$-Japan (ubiquitous Japan), a „mindenütt jelen levô Japán” programja lép életbe.
} 


\section{Technológiai-hálózati megközelítés}

Az információstársadalom-felfogás következô változata a technológiai-hálózati megközelítés. Ennek kiváló képviselóje, Manuel Castells az új társadalmi alakzatot többször információs társadalomnak, majd, miután elmélyedt a jelenség tanulmányozásában, egyértelmúen hálózati társadalomnak nevezi, viszont információs technológiai paradigmaként tárgyalja.

Felfogása szerint - az információs fejlődési módnak köszönhetően - az információ és a tudás az előzőtól eltérő fejlődést eredményez. A technológia pedig, amely számára „a tudományos tudásnak a dolgok elvégzésére szolgáló különféle reprodukálható eljárások pontos meghatározására való alkalmazását" jelenti, ${ }^{5}$ az 1970-es években az USAban végbement fejlődés nyomán új információs technológiává válik. Az információs technológia az információra irányul, mindent áthat, hálózati logikát követ, rugalmas és konvergens. ${ }^{6}$

Napjainkban információs technológiai forradalom megy végbe. Az információs technológiák többszörösen rétegződött hálózatot hoznak létre, és szabályozó funkciókat látnak el: egyrészt összekapcsolják a domináns társadalmi folyamatokat és funkciókat, másrészt szabályozzák a hálózatban való részvételt és az abból való kimaradást. Ezáltal erôsen integrált rendszer alakul ki.

Az információs kor társadalomszerkezete a termelés, a hatalom és a tapasztalat hálózataiból épül fel. „A hálózatok többszörösen átszövik egymást, a hálózatok közötti átjárás kódjai és kapcsolói válnak a társadalmak formálásának, vezetésének és félrevezetésének alapvetố forrásaivá." 7

Egy késốbbi tanulmányában Castells megerôsíti, hogy:

- Ami korunkban újdonság, az az információs technológiák új halmazának köszönhetố. Az új halmaz új technológiai paradigmaként fogható fel, amely a mikroelektronika, az információs és kommunikációs technológiák (IKT-k), valamint a géntechnológia köré összpontosul.

- A tudás és az információ nemcsak a hálózati társadalomban, hanem minden társadalomban központi szerepet játszott.

Castells ez utóbbi meggyőződése miatt szakított az „információs társadalom” kifejezéssel, és helyette a „hálózati társadalom” terminus technicus használata mellett döntött. ${ }^{8}$

Ha kitekintünk a világba, láthatjuk, hogy a hálózatitársadalom-felfogás politikai program szinten is megjelenik. Japánban - a dokumentumok szerint - a jelenleg érvényes e-Japan Strategy II. helyébe 2006-tól a u-Japan (ubiquitous network society - UNS) program lép, amelynek célja a mindenütt jelen levô hálózati társadalom kiépítése. ${ }^{9}$

${ }^{4}$ Magyarul: Nora, Simon - Minc, Alain 1979.

${ }^{5}$ Castells, Manuel 2005 (1996): 65.

${ }^{6}$ Castells, Manuel 2005 (1996): 116. skk.

${ }^{7}$ Castells, Manuel 2005 (1996): 600.

${ }^{8}$ Castells, Manuel, 2000: 9.

${ }^{9}$ http://www.itu.int $/$ itu-wsis/2005/D-23chairmans_report.pdf, valamint az u-Japan Fehér Könyv (White Paper). 
A program jelentốsen eltér a castellsi felfogástól. A " $4 U$ " négy alapelvére épül, és a 2010-2015-ig terjedó idôszakra három cél megvalósítását irányozza elő. Az alapelveket a ubiquitous (mindenütt jelen levô, vagyis bárhol, bármikor, bárki által használható hálózat), a universal (általános, azaz bárhol, bárki által könnyen igénybe vehetố kommunikáció), a user-oriented (felhasználóbarát, egyéni igényekhez alkalmazkodó technológiák) és a unique (egyedülálló, különleges egyéni és társadalmi vitalitás, kreativitás) szlogenek jelenítik meg. A 2015-ig elérni kívánt célok pedig a következók: 1. a mindenütt jelen levô hálózat kifejlesztése révén széles sávú hozzáférés biztosítása a teljes lakosság részére, 2. az IKT-alkalmazások fokozása a lakosság legalább 80\%-ánál, valamint 3. az IKT-használat növelése, vagyis olyan környezeti feltételek kialakítása, amelyek nyomán az IKT-használat hajlandósági szintje a lakosságnak legalább a 80\%-ánál fokozódik. ${ }^{10} \mathrm{~A} u$-Japan stratégia nem a rendszert, hanem a felhasználót állítja a középpontba azáltal, hogy megteremti a feltételeket, hogy bárki, bárhonnan és bármikor személyek közötti (person-to-person, P2P), személyek és objektumok közötti (person-to-object, P2O) vagy objektumok közötti (object-to-object, O2O) kapcsolatot tudjon létesíteni. A program megvalósítási módja politikai eszközökkel támogatott technológiai-hálózati felfogást tükröz.

\section{Tudástársadalmi megközelítés}

A fogalmi váltás kezdeményezése az Európai Unióban szintén kimutatható. Az ezredfordulón készült dokumentumok egy részében az információs társadalom mellett mind gyakrabban egy új társadalmi formáció, a „tudástársadalom” kifejezést hasznát ják. ${ }^{11}$ Maga a szó kulturális-szociológiai eredetú. A 20. század folyamán azonban a tudás ökonomizálódott és informatizálódott, kulturális vonatkozása pedig a „szervezett információ" jelentésre szúkült. A tudás szót maga a Bangemann-jelentés is szúkített értelemben használja (vö. tudásalapú gazdaság). A "tudástársadalom" kifejezés tehát sajátos technológiai-kulturális-gazdasági alakzatra utal.

A tényleges helyzet azonban bonyolultabb. Egyes dokumentumok - jellegüktól függóen - különbözó értelemben használják ezt a kifejezést is: vannak, amelyek a tudástársadalmat az információs társadalom elózményének, esetleg foglalatának tartják, mások pedig éppen fordítva, az információs társadalmat tekintik a tudástársadalom komponensének. ${ }^{12} \mathrm{Az}$ értelmezési sokszínüség további vảltczatait villantják fel azok a dokumentumok, amelyek „az információs társadalombó! a tudásalapú társadalomba”

${ }^{10}$ Japánban a DAI (digital acces index - 2002-ben) 0,75; Magyarországon 0,63. Néhány adat az EUROSTAT 2005 évkönyvéból: internet-hozzáférés háztartásonként 2005-ben EU-25 átlag 48\%, EU-15 átlag 53\%, Magyarország 22\%; interneten keresztül rendelés magánszemélyeknél: EU-25 átlag 17\%, EU-15 átlag 20\%, Magyarország 5\%; szélessávú hozzáférés (vállalatok): EU-25 átlag 63\%, Magyarország 48\%. Forrás. http://epp.eurostat.cec.eu.int/portal

${ }^{11}$ http://europa.eu.int/comm/employment_social/firsttime_de.html.

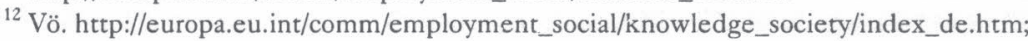
http://europa.eu.int/comm/employment_social/knowledge_society/shc_en.pdf 
való átmenet programját hirdetik, továbbá azok is, amelyek szerint a tudástársadalom a tudásalapú gazdaság egyik dimenziója. ${ }^{13}$

Összegezve a hivatalos dokumentumokat, megállapítható, hogy a tudástársadalom több rokon irányzat metszéspontjában helyezkedik el. A rokon irányzatok, trendek fogalmi körébe tartozik az információs társadalom fejlesztése új információs technológiák széles körben történố elterjesztése és használata alapján; továbbá az innováció (különösen a technológiai, de a szervezeti innováció) fontosságának növelése, a gazdaság szolgáltató szektorának fejlesztése, a tudásmenedzsment, valamint más fontos, említett pontokhoz kapcsolódó fejlesztések-fejlő́dések, ideértve a globalizációt, a demográfiai struktúrák, a kulturális szokások és a környezet terén végbemenô változásokat. ${ }^{14}$

\section{Szemantikai-pragmatikus megközelítés}

Eddigi tárgyalásaink során világossá vált, hogy mind az Európai Unióban, mind a világ más részein, illetve a szakemberek különféle köreiben eltérố információstársadalomfelfogás terjedt el. Mit jelent ez a gyakorlatban? A kérdés szemantikai-pragmatikus szempontból úgy vetôdik fel, hogy a fogalom és a valóság közötti kapcsolat hogyan interpretálható, mit jelent a fogalom a gyakorlatban, illetve hogyan közvetíti a gyakorlatot, és mi a teendő.

Az ilyen jellegú megközelítés azért is indokolt, mert az utóbbi idôben - miként az NHIT megállapítja - hiảba „egyeduralkodó” az EU-ban az „információs társadalom” kifejezés, jellegzetes használati módjai (IST - information society technologies, ICT information and communication technologies) ágazati jellegú beszúküléshez vezettek, miközben az oktatás, a tudomány, a kultúra vagy a média kérdései teljesen független tervezési „szigetekké” váltak.

Ahhoz, hogy a problémáról megfeleló véleményt formáljunk, Manuel Castells egyik lábjegyzetére hivatkozom, ahol a következóket írja: „az »információs « jelzố a társadalmi szerveződés specifikus formájára utal, amelyben a mai történelmi korszakban kialakuló új technológiai feltételek következtében az információ létrehozása, feldolgozása és továbbítása válik a termelékenység és a hatalom alapvető forrásává". ${ }^{15}$ Bár az információs társadalom kulcsfontosságú jellegzetessége a hálózati logika, egyéb összetevôi nem illeszkednek a hálózati logika rendszerébe. Ezért tér át Castells az „információs társadalom” helyett a „hálózati társadalom” kifejezés használatára: számára a valóság és a fogalom közötti megfelelést szemantikai-pragmatikus szempontból a hálózati társadalom biztosítja.

\footnotetext{
${ }^{13}$ http://europa.eu.int/comm/publications/booklets/move/36/de.doc. Auf dem Weg zur europäischen Wissensgesellschaft: Informationsgesellschaft in der Europäischen Union (Úton az európai tudástársadalomba: információs társadalom az Európai Unióban), 2002. október. Vö. még a következố szövegrésszel: „a tudástársadalom óriási potenciált foglal magában: új foglalkoztatási lehetôségeket, új segédeszközöket az általános és szakképzéshez, hátrányos helyzetû́ emberek és régiók integrációjának javítását és közszolgáltatásokhoz való könnyebb hozzáférését. Maga a »tudástársadalom « fogalma is arra utal, hogy a tudás és kreativitás mellett a humán és társadalmi tókébe mint értékes javakba történô beruházások veendók számításba.”

${ }^{14}$ Handbook of Knowledge Society Foresight.

${ }^{15}$ Castells, Manuel 2005 (1996): 57.
} 
Az Európai Unióban a Bangemann-jelentés nyomán a tagországok színvonaluknak megfelelốen kezdtek információstársadalom-építésbe. Mindegyik ország más-más irányba mozdult el. Az Elsó részjelentés (First Iterim Report, 1999) „az információs társadalom mint [...]" felfogás hat változatát nevezi meg. Az egyes változatok az új társadalmi formáció, illetve az annak kialakulásához vezető folyamat szúkített, célzott értelmezései. Mint Farkas János fogalmaz: „Noha mindegyik megközelítés megvilágítja az információnak és az információs technikának a jelenlegi átalakulási folyamatban betöltött szerepét, mégsincs egyetlen olyan közöttük, amely képes lenne egyedül átfogni a változás különbözô vonatkozásait." 16

Az idézett NHIT-közlemény további problémaként a technikai-technológiai beszúkítést nevezi meg. Az IST-k (magyarul: ITT-k - információs társadalmi technológiák) és az ICT-k (magyarul: IKT-k - információs és kommunikációs technikák) a társadalmi átalakulás során megfigyelhetố két technológiai dimenzióval azonosíthatók. A két szakkifejezés - tudományos szempontból - jelentôsen különbözik egymástól: az IKT-k valamely adott társadalomnak - s nem kizárólag az információs társadalomnak - az egyik infrastrukturális dimenziójára vonatkoznak, az ITT-k viszont az információs társadalomnak mint önálló entitásnak a technológiáit foglalják magukban. Ha elfogadjuk, hogy az információs társadalom egyik alapösszetevóje (alapdimenziója) a hálózat, akkor - mint másutt is megfogalmaztam - igaz az a megállapítás, hogy „,a hálózatok » magvát « az információs és kommunikációs technikák alkotják, amelyeket szolgáltatók infokommunikációs rendszerekként múködtetnek. A kapcsolatokat az egyes felhasználók között, illetóleg a homo informaticusok információalapú társadalmi kommunikációját, vagy egyszerúen a gépi információáramlást ágensek, multiágensek és ezek kapcsolódásai tartják fenn és bonyolítják le". ${ }^{17} \mathrm{Ez}$ azt jelenti, hogy a hálózat nem azonos sem az IKT-kkal, sem az ITT-kkel, ugyanakkor ez utóbbiak technológiákként fenntartják és múködtetik az információs társadalmat.

A hálózat általam vallott felfogása hasonlít a $u$-Japan stratégiában megfogalmazott „mindenütt jelen levő társadalom” értelmezéséhez: „Egy mindenütt jelen levô társadalom olyan társadalom, amely lehetôvé teszi, hogy »bármikor, bárhol, bármi és bárki « varratmentesen is kapcsolatot létesítsen, és elérhetố, olcsó és felhasználóbarát eszközök segítségével nagy mennyiségben információt cseréljen." ${ }^{18}$ Minthogy a hálózat nem azonos magával az információs társadalommal, a ubiquitous society sem tekinthetố annak. Mind az IKT-k, mind az ITT-k a hálózat, s következésképpen az információs társadalom részét képezik, ezért jelentéstartományuk is csak szúkebb lehet.

A fentiekben leírtak megerôsítik korábbi felfogásomat, mely szerint az információs társadalom olyan alakzat vagy intézmény, amelyben a funkciók, a cselekvések és a struktúrák

- új logikai felépítéssel rendelkeznek,

- sajátos szabályszerúségek szerint múk ödnek, valamint

- lényegesen különböznek minden előzô vagy velük egyidejúleg létezố társadalmi alakzat intézményi és múködési rendjétól.

${ }^{16}$ Vö. Farkas János: Elméletek az információs társadalomról. In Balogh Gábor (szerk.), 2006.

${ }^{17}$ Balogh Gábor: Az információs társadalom komponensei. In Balogh Gábor (szerk.), 2006.

${ }^{18}$ Tokyo Ubiquitous Network Conference, Toward the realization of a Ubiquitous Network Society. Chairman's report, 2005. 
Úgy vélem, az információs társadalom egyes számban legfeljebb gyújtőfogalomként használható. Miként láttuk, ahány régió, annyi információs társadalomról lehet szó. Ezért tudományos szempontból helyesebb információs társadalmakról beszélni.

\section{Kitekintés}

Ha az információs társadalom eredettörténetét vizsgáljuk, megállapítható, hogy a szakkifejezés a nyugati világban elkötelezett szakemberektól (vö. Daniel Bell, 1974; Manuel Castells, 2005 [1996]), vagy politikai megrendelésre dolgozó tanácsadóktól (vö. Simon Nora és Alain Minc, 1979 [1978]) származik, illetóleg politikai célok megvalósítása érdekében született (vö. Marc Uri Porat, 1977; Bangemann-jelentés, 1994). Nincs egységes definíciója, mindenki más értelemben használja. Következésképpen nincs egységes információs társadalom sem. Ez - önmagában véve - nem is baj. A probléma akkor kezdôdik, amikor hivatalos álláspontot akarnak elfogadtatni, és ehhez az értelmezések sokszínúségét uniformizálni szeretnék. Ekkor az egységesítésre törekvôk szembesülnek a különböző dimenziók összemérhetetlenségével, s azzal a dilemmával, amit a konstruktivizmus a következóképpen fogalmaz meg: a tudomány nem tudományos, hanem társadalmi termék. A tudományfilozófia pedig ezt mondja: konvenció kérdése, mit nevezünk tudománynak. Ennek parafrázisaként: konvenció kérdése, mit jelent az információs társadalom. A konvenció kialakításában a politikai hatalom komoly szerepet vállalhat magára. Kérdés, megéri-e a hatalomnak, hogy elkötelezódjék valamely adott irányzat vagy megközelítési mód mellett.

Meglátásom szerint sem a politikai hatalomnak, sem másnak nem érdemes dogmatikussá tenni egy megközelítést, illetve dogmatikus módon viszonyulni az információs társadalom problematikájához, hacsak nem kívánja a demokrácia helyett vagy amellett az információs társadalom építését politikai programmá tenni. Ebben az esetben az „információs társadalom” kifejezés könnyen politikai ideológiává emelkedhet, aminek szükségszerú következménye, hogy szúkül a kifejezés jelentésbeli és értelmezési lehetőségeinek sokszínưsége.

\section{Irodalom}

Balogh Gábor (szerk.) (2006): Az információs társadalom dimenziói. Budapest: Gondolat Kiadói Kör. Bangemann-jelentés (1994). In Mi a jövó? Az információs társadalom és a magyar kezdeményezések. Budapest: OMFB-ORTT-HÉA, 1998, 44-79.

Bell, Daniel (1974): The coming of post-industrial society. A venture in social forecasting. London: Heinemann.

Bell, Daniel (2001): Az információs társadalom társas keretrendszere. In Információs Társadalom, $1,3-33$.

Castells, Manuel (2000): Materials for an exploratory theory of the network society. In British Journal of Sociology, Vol. No. 51, Issue No. 1 (January/March 2000), 5-24. Castells, Manuel (2005 [1996]): A hálózati társadalom kialakulása. Budapest: Gondolat Kiadói Kör.

Building the knowledge society: social and human capital interactions (2003). Brussels: Commission staff working paper, SEC (2003), 652. 
Handbook of Knowledge Society Foresight. Dublin, Ireland: @ European Foundation for the Improvement of Living and Working Conditions, 2003. www.eurofound.eu.int.

Machlup, Fritz (1962): The production and distribution of knowledge in the United States. Princeton, NJ: Princeton University Press.

Machlup, Fritz (1980-1984): Knowledge: its creation, distribution and economic significance I-III. Princeton, NJ: Princeton University Press.

Mattelart, Armand (2004 [2003]): Az információs társadalom története. Budapest: Gondolat Kiadói Kör.

Nora, Simon - Minc, Alain (1979 [1978]): A számítógépesitett társadalom:jelentés a francia köztársasági elnök részére. Budapest: Statisztikai Kiadó Vállalat. Eredeti: L'informatisation de la . Paris: Éd. Seuil.

Porat, Marc Uri (1977): The information economy: definition and measurement. Washington DC: Government Printing Office. 